\title{
Analiza regionów genomu sprzężonych z odpornością porzeczki czarnej (Ribes nigrum) na wielkopąkowca porzeczkowego (Cecidophyopsis ribis)
}

\author{
Analysis of genome regions linked to the resistance of blackcurrant (Ribes nigrum) \\ to blackcurrant gall mite (Cecidophyopsis ribis)
}

\section{Anita Kuras ${ }^{\varpi}$, Bogumiła Badek}

Zakład Hodowli Roślin Ogrodniczych,

Instytut Ogrodnictwa, ul. Konstytucji 3 Maja 1/3, 96-100 Skierniewice

$\bowtie$ e-mail: anita.kuras@inhort.pl

\begin{abstract}
Wielkopąkowiec porzeczkowy (Cecidophyopsis ribis), jest jednym z najgroźniejszych szkodników porzeczki czarnej. Powoduje on deformację pąków porzeczki czarnej i redukuje plon owoców. Wybranie najkorzystniejszych markerów molekularnych sprzężonych z odpornością na wielkopąkowca porzeczkowego może przyspieszyć proces hodowlany i poprawić skuteczność przy wyborze genotypów odpornych na tę chorobę. Celem pracy była analiza regionów genomu sprzężonych z odpornością porzeczki czarnej (Ribes nigrum) na wielkopąkowca porzeczkowego poprzez ocenę stopnia polimorfizmu w grupach sprzężeń obejmujących regiony Ce i P i poszukiwanie nowych fragmentów genomu regulujących odporność na $C$. ribis. W wyniku analizy elektroforegramów z produktami reakcji CAPS, zidentyfikowano 119 polimorficznych fragmentów DNA, z których wytypowano 100 do analizy sekwencji. W wyniku sekwencjonowania uzyskano 9 specyficznych odczytów na matrycach DNA odmian 'Ceres', 'Ojebyn', 'Vir', 'Ores', 'Foxendown', 'Ben Finlay'i ‘Bona'.
\end{abstract}

Słowa kluczowe: CAPS, Cecidophyopsis ribis, marker molekularny, porzeczka czarna,

Blackcurrant gall mite (Cecidophyopsis ribis) is one of the most dangerous pests of blackcurrant. It causes deformation of blackcurrant buds and reduces fruit yield. The selection of the most favorable molecular markers coupled to resistance to C.ribis, can accelerate the breeding process and improve efficacy when choosing genotypes that are resistant to this disease. The aim of this study was to analyze genome regions conjugated with resistance of blackcurrant (Ribes nigrum) to blackcurrant gall mite by assessing the degree of polymorphism in coupling groups, including the Ce and $\mathrm{P}$ regions, and by searching for new genome fragments regulating $C$. ribis resistance. As a result of the analysis of electrophoregrams with CAPS reaction products, 119 polymorphic DNA fragments were identified, out of which 100 were selected for sequence analysis. As the end product of sequencing, 9 specific readings were obtained on DNA matrices of the varieties 'Ceres', 'Ojebyn', 'Vir', 'Ores', 'Foxendown', 'Ben Finlay' and 'Bona'.

Key words: CAPS, Cecidophyopsis ribis, molecular marker, blackcurrant

\section{Wstęp}

Wielkopąkowiec porzeczkowy (Cecidophyopsis ribis), najgroźniejszy szkodnik w uprawie czarnej porzeczki, jest wektorem rewersji porzeczki czarnej (BRV - Black Currant Reversion Virus), która redukuje plon, prowadząc w konsekwencji do likwidacji plantacji (Pluta i Żurawicz, 2002; Łabanowska i in., 2015). Ograniczanie liczebności populacji wielkopąkowca porzeczkowego oraz pozyskanie odmian porzeczki czarnej o zwiększonej odporności na szpeciela i BRV są niezwykle istotne dla praktyki ogrodniczej. Wiele jednostek naukowych w Europie zajmuje się badaniami nad identyfikacją markerów molekularnych, sprzężonych z dwoma odrębnymi typami odporności Ce i P. Źródłem odporności typu Ce w w/w badaniach jest agrest ( $R$. grossularia) (Knight i in., 1974; Brennan i in., 1993), a typu $\mathrm{P}-R$. nigrum ssp. Sibiricum (Anderson, 1971). W Instytucie Ogrodnictwa w Skierniewicach prowadzone są badania dotyczące poszukiwania sprzężeń między odpornością, a zlokalizowaniem warunkujących ją fragmentów genomu na mapie genetycznej porzeczki czarnej. Celem przedstawionych badań prowadzonych w 2019 roku była: ocena polimorfizmu w grupach sprzężeń obejmujących regiony związane z cechą odporności porzeczki na C. ribis, oparta na metodzie sekwencjonowania. 


\section{Material i Metody Material badawczy}

Badania przeprowadzono na roślinach 12 genotypów rodzaju Ribes (6 odpornych i 6 wrażliwych na $C$. ribis), wytypowanych do badań na podstawie danych literaturowych oraz analiz przeprowadzonych $\mathrm{w}$ ramach realizacji projektu $\mathrm{w}$ latach 2015-2019 (Tab. 1).

\section{Metody badawcze}

DNA z wytypowanych genotypów wyekstrahowano z młodych liści metodą Doyle i Doyle (1990). Jakość i koncentrację DNA w uzyskanych próbach określano na podstawie elektroforegramów w $0,8 \%$ żelu agarozowym oraz w oparciu o pomiar współczynników ekstynkcji próbki przy długości fali 230, 260, 280 i 320 nm (Gene Quant Pro Amersham Pharmacia Biotech).

Na matrycy DNA wyekstrahowanego z badanych genotypów rodzaju Ribes (Tab. 1) przeprowadzono reakcje amplifikacji z kombinacjami starterów SSR (Tab. 2) wytypowanych do badań w oparciu o bazy danych (na podstawie lokalizacji regionów blisko sprzężonych z QTL warunkującymi odporność na wielkopąkowca porzeczkowego - $\operatorname{Lg} 2^{*}$; LG4* i LG6** Brennan i in., 2008* i Mazeikiene i in., $2012^{* *}$ ) oraz wyniki uzyskane $\mathrm{w}$ trakcie realizacji projektu w latach 2015-2019.

Tabela 1

Table 1

Wykaz genotypów rodzaju Ribes, wytypowanych do analiz molekularnych

List of genotypes of the genus Ribes selected for molecular analysis

\begin{tabular}{|c|c|c|c|c|}
\hline $\begin{array}{l}\text { Lp. } \\
\text { No. }\end{array}$ & $\begin{array}{l}\text { Odmiana } \\
\text { Variety }\end{array}$ & $\begin{array}{l}\text { Rodowód } \\
\text { Parentage }\end{array}$ & $\begin{array}{c}\text { Wrażliwa } \\
\text { Odporna }^{1} \\
\text { Suscepribility } \\
\text { Resistant } \\
\end{array}$ & $\begin{array}{c}\text { Kraj } \\
\text { Country }\end{array}$ \\
\hline 1. & Ores & $($ Ojebyn $\times$ S24 $) \times$ Ceres & odporna & Polska \\
\hline 2. & Ceres & (R. Dikuscha $\times$ Barchatnaja $) \times$ samozapylenie & odporna & Polska \\
\hline 3. & Polares & $\mathrm{S} 12 / 3 / 83 \times \mathrm{EMB}(1834) / 113$ & odporna & Polska \\
\hline 4. & Foxendown & $\begin{array}{c}\text { Ben LomondD x }(\mathrm{BC} 3 \mathrm{z} \text { agrestu } \times \mathrm{BC} 2 \text { R. Glutino- } \\
\text { sum })\end{array}$ & odporna & Szkocja \\
\hline 5. & Vir & nieznany & odporna & Rosja \\
\hline 6. & Ben Finlay & [(SCRI P10/9/13 × Ben Alder $) \times$ EM B1834-67] & odporna & Szkocja \\
\hline 7. & Ben Hope & Westra x (SCRI 238/36 × EM 21/15) & wrażliwa & Szkocja \\
\hline 8. & Bona & Ojebyn $\times($ R.Dikuscha $\times$ Climax $)$ & wrażliwa & Polska \\
\hline 9. & Gofert & Gołubka $\times$ Fertodi 1 & wrażliwa & Polska \\
\hline 10. & Gołubka & R. Nigrum $\times$ R. Dikuscha. & wrażliwa & Rosja \\
\hline 11. & Ojebyn & Seedling selection of $R$. Nigrum from north sweden & wrażliwa & Szkocja \\
\hline 12. & Riasnaja & nieznany & wrażliwa & Rosja \\
\hline
\end{tabular}

Tabela 2

Wykaz starterów SSR użytych do analiz molekularnych

Table 2

List of SSR primers used for molecular analysis

\begin{tabular}{|c|c|c|c|}
\hline $\begin{array}{l}\text { Starter } \\
\text { Primer }\end{array}$ & \multicolumn{2}{|c|}{$\begin{array}{l}\text { Sekwencja startera }\left(5^{\prime}-3^{\prime}\right) \\
\text { Starter sequence }\left(5^{\prime}-3^{\prime}\right)\end{array}$} & $\begin{array}{l}\text { Lokalizacjana chromosomach } \\
\text { Location on the chromosome }\end{array}$ \\
\hline g1-G06F/g2-J08R & AAAACACACATCTCTCACCCC & ATAGCCCATGCCCATATTCA & $\mathrm{LG} 2^{*}$ \\
\hline g2-J08F/g1-G06R & CGCCGAGCTCTAATCACTGT & TCGAATCTGAACCACGATGA & $\mathrm{LG} 2^{*}$ \\
\hline g2-J08F/g1-B02R & CGCCGAGCTCTAATCACTGT & CCATTGATTTGGTGAGGGT & $\mathrm{LG} 2^{*}$ \\
\hline g1-B02F/g2-J08R & CGCTTCATCGCTCTCCTCT & ATA GCC CAT GCC CAT ATT CA & $\mathrm{LG} 2^{*}$ \\
\hline g1-G06F/g1-B02R & AAAACACACATCTCTCACCCC & CCA TTG ATT TGG TGA GGG T & LG $2^{*}$ \\
\hline g1-B02F/g1-G06R & CGACTTCATCGCTCTCCTCT & TCG AAT CTG AAC CAC GAT GA & LG $2^{*}$ \\
\hline e1-O21F/g2-L17R & TCTCTCCAACTGAGAAGGAAA & GAG CTG TTG CTG TTG CCA TA & LG $4^{*}$ \\
\hline g2-L17F/e1-O21R & TTTGGA AAA CCT CCC CTT TT & GAT TTG TTC TTG TGC AGC GA & LG $4^{*}$ \\
\hline g1-I02F/g1-D11R & TGA ATA TCA GAC CGC CAT CA & AAT CGA ATG GAA TCG TCC & $\mathrm{LG}^{* *}$ \\
\hline g1-D11F/g1-I02R & GAA GAC GAC AAA GCC TCC & $\begin{array}{c}\text { TCC AAG ATG AAG CTT CTC } \\
\text { AAA TC }\end{array}$ & $\mathrm{LG}^{* *}$ \\
\hline
\end{tabular}

${ }^{*}$-Brennan i in. 2008; ${ }^{* *}$-Mazeikiene i in. 2012 
Mieszanina reakcyjna $\mathrm{w}$ przeprowadzonych testach PCR zawierała: 10 ng DNA, 0,5U polimerazy Taq Platinum ${ }^{\circledR}$ (Invitrogen), $10 \times$ PCR-buforu, $1,5 \mathrm{mM} \mathrm{MgCl}_{2}, 1,25 \mathrm{mM}$ dNTP (Applied Biosystems) i 0,35 $\mu \mathrm{M}$ startera SSR (zgodnie z zaleceniami producenta). Zastosowano profil termiczny reakcji: wstępna denaturacja $-94^{\circ} \mathrm{C} / 2$ min, 4 cykle (denaturacja $94^{\circ} \mathrm{C} / 50 \mathrm{~s}$, przyłączanie startera $55-50^{\circ} \mathrm{C} / 50 \mathrm{~s}$ (w każdym kolejnym cyklu spadek temperatury przyłączania o $1^{\circ} \mathrm{C}$ ), wydłużanie nici DNA $72^{\circ} \mathrm{C} / 60 \mathrm{~s}$ ), 30 cykli (denaturacja $94^{\circ} \mathrm{C} / 50 \mathrm{~s}$, przyłączanie startera $55-50^{\circ} \mathrm{C} / 90 \mathrm{~s}$, wydłużanie nici DNA $72^{\circ} \mathrm{C} / 60 \mathrm{~s}$ ), wydłużanie końcowe $72^{\circ} \mathrm{C} / 10$ min. Reakcję przeprowadzono $\mathrm{w}$ termocyklerze Biometra Basic.

Produkty reakcji SSR-PCR poddano trawieniu 4 enzymami restrykcyjnymi (Tab. 3), które rozdzielono w $2 \%$ żelu agarozowym, wybarwionym bromkiem etydyny, następnie charakterystyczne dla analizowanych genotypów fragmenty DNA wyizolowano z żeli agarozowych, przy użyciu zestawu komercyjnego FastGene Gel/PCR Extraction Kit (Nippon Genetics), według procedury dołączonej przez producenta.

Wyizolowane z żelu i oczyszczone fragmenty DNA wklonowano do plazmidów bakteryjnych $\left(\mathrm{TOPO}^{\circledR}\right.$ TA Cloning ${ }^{\circledR}$ Kit for Sequencing (Invitrogen). Następnie plazmidy umieszczono w ukompetentnionych bakteriach $E$. coli One shot TOP10 (Invitrogen), według protokołu producenta. Po wyselekcjonowaniu, wybrane kolonie bakteryjne, zawierające plazmid z wstawionym fragmentem DNA analizowanych genotypów Ribes, przeniesiono na pożywkę płynną LB. Po inkubacji $\left(37^{\circ} \mathrm{C} / 16 \mathrm{~h}\right)$ z zawiesiny bakterii, wyizolowano plazmid bakteryjny przy użyciu komercyjnego zestawu FastGene Plasmid Mini Kit (Nippon Genetics).

Plazmidy bakteryjne zawierające charakterystyczne fragmenty genomu wyznakowano w reakcji PCR z uniwersalnym starterem M13, stosując zestaw DTCS Quick Start Kit (Beckman Coulter), a następnie poddano sekwencjonowaniu przy użyciu systemu CEQ (8000) Genome Analyzer (Beckman Coulter).
Analizę sekwencji przeprowadzono przy użyciu programu CEQ (8000) software v.9.0. Uzyskane z odczytów kontigi 'składano' przy użyciu programu SeqMan (pakiet Lasergen v.7). Zróżnicowanie nukleotydowe sekwencji analizowano przy użyciu programu MegAlign (pakiet Lasergen v.7). Uzyskane sekwencje DNA porównano $z$ danymi NCBI za pomoca programu bioinformatycznego blast-nt.

Do uzyskanych sekwencji DNA zaprojektowano specyficzne oligonukleotydy (program komputerowy PrimerSelect- pakiet Lasergen v.7).

\section{Wyniki}

Po zidentyfikowaniu polimorfizmów pomiędzy genotypami wrażliwymi/odpornymi na $C$. ribis, uzyskane sekwencje analizowano za pomocą programu MegAlign (pakiet Lasergen v.7), aby sprawdzić, czy możliwe jest przekształcenie polimorfizmu w marker CAPS. Analiza, umożliwiła wytypowanie czterech enzymów restrykcyjnych: PstI, Tru1I, AseI, SmaI, które spełniały następujące założenia: długości produktów uzyskanych po reakcji cięcia musiały pozwolić na wyraźnie rozróżnienie alleli, obecność maksymalnie trzech miejsc cięcia w analizowanej sekwencji (Tab. 3).

Po przeprowadzeniu łącznie 1440 reakcji amplifikacji PCR z 10 parami starterów flankujących regiony $\mathrm{Ce}$ i $\mathrm{P}$ w różnych kombinacjach (Tab. 2), które poddano trawieniu przy użyciu wytypowanych enzymów restrykcyjnych, w wyni$\mathrm{ku}$ analizy elektroforegramów, zidentyfikowano 119 polimorficznych fragmentów DNA, z których do analizy wytypowano 100 sekwencji (Tab. 4). W wyniku sekwencjonowania uzyskano 9 specyficznych odczytów o długości od 351 do $490 \mathrm{pz}$ (Tab. 5).

Analiza porównawcza uzyskanych sekwencji wykazała zróżnicowanie układu sekwencji amplikonów uzyskanych dla badanych genotypów odpornych i wrażliwych, najprawdopodobniej sklasyfikowanych jako polimorfizm jednonukleotydowy (SNP). Do uzyskanych sekwencji zaprojektowano po jednej parze specyficznych oligonukleotydów (Tab. 6)

Tabela 3

Table 3

Wykaz enzymów restrykcyjnych użytych do analizy CAPS

List of restriction enzymes used for CAPS analysis

\begin{tabular}{|c|c|c|c|c|}
\hline $\begin{array}{l}\text { Enzym } \\
\text { Enzyme }\end{array}$ & $\begin{array}{l}\text { Pochodzenie } \\
\text { Origin }\end{array}$ & $\begin{array}{l}\text { Rozpoznawana sekwencja } \\
\text { Recognized sequence }\end{array}$ & $\begin{array}{c}\text { Warunki reakcji } \\
\text { Reaction conditions }\end{array}$ & $\begin{array}{l}\text { Inaktywacja } \\
\text { Inactivation }\end{array}$ \\
\hline PstI & Providencia stuarti & 5'...CTGCA G...3' & $37^{\circ} \mathrm{C} / 16 \mathrm{~h}$ & $80^{\circ} \mathrm{C} / 20 \mathrm{~min}$ \\
\hline Tru1I & Thermus ruber & $5^{\prime} \ldots$ T ТАА.... $3^{\prime}$ & $65^{\circ} \mathrm{C} / 16 \mathrm{~h}$ & $80^{\circ} \mathrm{C} / 20 \mathrm{~min}$ \\
\hline AseI & Vibrio species & $5^{\prime} \ldots$ АТ ТАA... $3^{\prime}$ & $37^{\circ} \mathrm{C} / 16 \mathrm{~h}$ & $65^{\circ} \mathrm{C} / 20 \mathrm{~min}$ \\
\hline SmaI & Serratia marcescens & $5^{\prime}, \ldots \mathrm{CCC}$ GGG ...3' & $30^{\circ} \mathrm{C} / 16 \mathrm{~h}$ & $65^{\circ} \mathrm{C} / 20 \mathrm{~min}$ \\
\hline
\end{tabular}


Wykaz fragmentów DNA wytypowanych do analizy sekwencji.

List of DNA fragments selected for sequence analysis.

\begin{tabular}{|c|c|c|c|c|c|c|c|c|c|c|c|c|c|}
\hline \multirow[b]{2}{*}{$\begin{array}{c}\text { Starter/enzym } \\
\text { Primer/enzyme }\end{array}$} & \multirow{2}{*}{$\begin{array}{c}\text { Długość } \\
{[\mathrm{Pz}]} \\
\text { Fragmentów dna } \\
\text { Band size of dna fragments (bp) }\end{array}$} & \multicolumn{12}{|c|}{$\begin{array}{c}\text { Analizowane genotypy } \\
\text { Analyzed genotypes }\end{array}$} \\
\hline & & $\stackrel{\mathscr{E}}{0}$ & Uूँ & $\frac{0}{0}$ & $\begin{array}{l}5 \\
0 \\
0 \\
0 \\
0 \\
0 \\
0 \\
0 \\
\end{array}$ & $j$ & 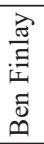 & 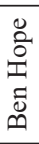 & $\underset{\overparen{0}}{\tilde{0}}$ & 苞 & $\begin{array}{l}\frac{\pi}{3} \\
\frac{3}{3} \\
0 \\
0\end{array}$ & $\frac{5}{\frac{0}{0}}$ & 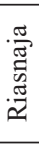 \\
\hline \multirow{4}{*}{$\begin{array}{c}\text { g1-G06F/ } \\
\text { g2-J08R/ } \\
\text { PstI }\end{array}$} & 360 & $+^{1}$ & + & + & + & + & + & + & + & + & + & + & + \\
\hline & 390 & + & + & & + & & + & + & & & + & + & + \\
\hline & 430 & + & + & + & + & + & + & + & + & + & + & + & + \\
\hline & 490 & + & + & & & + & & & + & + & + & & \\
\hline \multirow{2}{*}{$\begin{array}{c}\mathrm{g} 1-\mathrm{B} 02 \mathrm{~F} / \\
\mathrm{g} 1-\mathrm{G} 06 \mathrm{R} / \\
\text { AseI }\end{array}$} & 300 & + & & + & + & + & + & & & & & + & + \\
\hline & 340 & + & + & + & + & + & + & + & + & + & + & + & + \\
\hline \multirow{3}{*}{$\begin{array}{c}\mathrm{g} 1-\mathrm{G} 06 \mathrm{~F} / \\
\mathrm{g} 2-\mathrm{J} 08 \mathrm{R} / \\
\text { AseI }\end{array}$} & 350 & & + & & & + & + & + & + & + & & & \\
\hline & 460 & + & + & + & + & + & + & + & + & + & + & + & + \\
\hline & 510 & + & + & + & + & + & + & + & + & + & + & + & + \\
\hline \multirow{2}{*}{$\begin{array}{c}\mathrm{g} 1-\mathrm{B} 02 \mathrm{~F} / \\
\mathrm{g} 1-\mathrm{G} 06 \mathrm{R} / \\
\text { SmaI }\end{array}$} & 430 & & + & & & + & + & + & + & & & & \\
\hline & 580 & + & + & + & + & & & + & + & + & & & + \\
\hline
\end{tabular}

1_,, ", fragment wytypowany do sekwencjonowania

Wykaz specyficznych sekwencji uzyskanych w wyniku sekwencjonowania

Table 5 List of specific sequences obtained as a result of sequencing

\begin{tabular}{|c|c|c|c|c|}
\hline $\begin{array}{l}\text { Lp. } \\
\text { No. }\end{array}$ & $\begin{array}{l}\text { Nazwa sekwencji } \\
\text { Sequence name }\end{array}$ & $\begin{array}{c}\text { Pochodzenie/genotyp } \\
\text { Origin/ } \\
\text { Genotype }\end{array}$ & $\begin{array}{c}\text { Kombinacje starterów } \\
\text { Flankujących regiony ce i p/enzym } \\
\text { Primers flanking regions } \\
\text { ce and p/enzyme }\end{array}$ & $\begin{array}{c}\text { Wielkość zsekwencjonowanego } \\
\text { fragmentu dna } \\
{[\mathrm{Pz}]} \\
\text { Dna band size [bp] } \\
\end{array}$ \\
\hline 1 & Seq. 73 & 'Ceres’ & $\mathrm{g} 1-\mathrm{G} 06 \mathrm{~F} / \mathrm{g} 2-\mathrm{J} 08 \mathrm{R} / P_{s t I}$ & 363 \\
\hline 2. & Seq. 74 & 'Ojebyn' & g1-G06F/g2-J08R/ PstI & 390 \\
\hline 3. & Seq. 75 & 'Vir' & g1-G06F/g2-J08R/ PstI & 490 \\
\hline 4. & Seq. 76 & 'Ceres' & g1-G06F/g2-J08R/AseI & 351 \\
\hline 5. & Seq. 77 & 'Ores' & g1-G06F/g2-J08R/AseI & 460 \\
\hline 6. & Seq.78 & 'Foxendown' & g1-G06F/g2-J08R/AseI & 462 \\
\hline 7. & Seq. 79 & 'Vir' & g1-G06Fg2-J08R/AseI & 461 \\
\hline 8. & Seq. 80 & 'Ben Finlay' & g1-B02F/g1-G06R/SmaI & 435 \\
\hline 9. & Seq. 81 & 'Bona' & g1-B02F/g1-G06R/SmaI & 436 \\
\hline
\end{tabular}

Wykaz sekwencji oligonukleotydów specyficznych

Table 6 List of specific oligonucleotide sequences

\begin{tabular}{c|c|c|c|}
\hline $\begin{array}{c}\text { Lp. } \\
\text { No.. }\end{array}$ & $\begin{array}{c}\text { Oligonukleotyd } \\
\text { Oligonucleotide }\end{array}$ & Reverse & Forvard \\
\hline 1. & 2.73 & CTCGCTGAGCGGATTTGGAT & ACGGCGGTTAGGAAGGTGTGGGT \\
2. & 2.74 & CGATAGCGGGACTGTAAGAG & TTATGAGCCCCAAAGCCCTAAG \\
3. & 2.75 & CGTGGTATGACATCAGACTACAC & ACGGACTGGACCGGGAC \\
4. & 2.76 & T AGTGAAGAACGGAGCTCAGGAG & TTTATTGCGGAGGGAGAGGCGCT \\
5. & 2.77 & CCGACCATACTTGAGTCGTAATAG & ACTGATTTCCCCCGAGCTCTTG \\
6. & 2.78 & GAGGCTAAGAAGGACGTGTATGGG & TAGGATGCTTCCCGTCAATACGA \\
7. & 2.79 & GCCGAGTTTCTGTATCGTGCA & CGAATAAGTCAGGGCGCATAGGC \\
8. & 2.80 & TCTTGTCAACTCGGCTCCCAGACT & CAGGGCAGAAAGCTGTGGAGGGAA \\
9. & 2.81 & TGAGTTCATCGCCATCAGACATG & GAAGGGCGAATGGAGGGCTGATAT \\
\hline
\end{tabular}




\section{Dyskusja}

Ze względu na cenne walory zdrowotne porzeczki czarnej na całym świecie prowadzone są badania, których celem jest znalezienie odmian odpowiednich do uprawy w danych warunkach klimatycznych, o podwyższonej tolerancji na niską temperaturę oraz choroby stanowiące zagrożenie (głównie rewersja porzeczki czarnej) i szkodniki (wielkopąkowiec porzeczkowy). Ograniczanie liczebności populacji wielkopąkowca porzeczkowego oraz pozyskanie odmian porzeczki czarnej o zwiększonej odporności na szpeciela i BRV są niezwykle istotne dla praktyki ogrodniczej. Dotychczas zidentyfikowano, w oparciu o wyniki prac genetyczno-hodowlanych, dwa odrębne typy odporności na wielkopąkowca (Brennan i in., 2008; Mazeikiene i in., 2012), których źródłem jest agrest (R. grossularia) (Knight i in., 1974) i R. nigrum ssp. Sibiricum (Anderson 1971).

Wykorzystanie markerów molekularnych w hodowli roślinnej zwiększa efektywność konwencjonalnej hodowli, poprzez selekcję roślin posiadających markery sprzężone $\mathrm{z}$ ważnymi gospodarczo cechami użytkowymi (Gupta i wsp.1999). Poszukiwanie i identyfikacja takich markerów ma na celu skrócenie cyklu hodowlanego, gdyż selekcję materiału roślinnego można przeprowadzić już w stadium siewki, niezależnie od tego, w jakiej fazie rozwojowej rośliny ujawnia się dana cecha. W hodowli odpornościowej poszukujemy markerów sprzężonych z cechami odporności, a do selekcji (MAS) wystarczający może być pojedynczy marker lub zestaw markerów sprzężonych z tą cechą.

W 2019 roku kontynuowano badania dotyczące oceny polimorfizmu $\mathrm{w}$ grupach sprzężeń obejmujących regiony związane z cechą odporności, oparte na metodzie sekwencjonowania. Działanie najpopularniejszych sekwenatorów, wykorzystywanych do badań naukowych i diagnostycznych, polega na modyfikacji metody opracowanej przez Sangera i Coulsona w 1975 r. W badaniach dotyczących sekwencjonowania genomów rodzaju Ribes wykorzystaliśmy sekwenator CEQ (8000) Beckman Coulter. Metoda sekwencjonowania często stosowana jest do analiz porównawczych (alignment) i identyfikacji jednonukleotydowych różnic w obrębie tego samego fragmentu (SNP: Single Nucleotide Polymorphism) (Bang i in., 2007; Thiel $\mathrm{i}$ in., 2004). Porównania takie dostarczają szczegółowych informacji na temat podobieństwa/zróżnicowania genetycznego, pochodzenia i ewolucji badanych organizmów.

Prowadzone w naszych badaniach wstępne analizy porównawcze sekwencji DNA charakterystycznych dla genotypów rodzaju Ribes zróżnicowanych pod względem odporności na wielkopąkowca porzeczkowego pozwoliły na poszerzenie bazy danych dotyczących polimorfizmu odmian porzeczki podatnych i odpornych dla potrzeb analizy regulacji zjawiska odporności na wielkopąkowca porzeczkowego $C$. ribis.

Analiza porównawcza zsekwencjonowanych fragmentów DNA zidentyfikowanych w w/w genotypach wykazała silną homologię (88-90\%) z sekwencją nukleotydów markera Ce zaprezentowaną przez Brennana i wsp. (2008). Obecnie, badania naukowców koncentrują się na rozpoznaniu sposobów dziedziczenia genów odporności $(\mathrm{Ce}$ i $\mathrm{P})$ w genotypach uzyskanych w wyniku hybrydyzacji gatunków, u których stwierdzono ich występowanie.

W naszej pracy również poszukujemy markerów sprzężonych z genami odporności $C e$ i $P$, które umożliwiłyby charakterystykę genotypów rodzaju Ribes, zróżnicowanych pod względem odporności. Na obecnym etapie badań, przeprowadzone przez nas wstępne badania weryfikujące wytypowane sekwencje markerowe, nie potwierdziły ich przydatności do selekcji genotypów odpornych i wrażliwych na wielkopąkowca porzeczkowego.

\section{Wnioski}

Wyniki badań dotyczące oceny polimorfizmu fragmentów różnicujących genotypy rodzaju Ribes (odporne/podatne) uzyskane na matrycach DNA roślin wybranych zkolekcji stanowią podstawę bazy sekwencji sprzężonych z cechą odporności na C. ribis.

Badania finansowano ze środków projektu MRiRW: Badania podstawowe na rzecz postepu biologicznego $w$ produkcji decyzja HOR. hn.802.4.2019 z dnia 14.05.2019 r., Zadanie $n r 78$

\section{Literatura}

Anderson, M. M. (1971). Resistance to gall mite (Phytoptus ribis Nal.) in the Eucoreosma section of Ribes. Euphytica (20), 422-426.

Bang, H., Kim, S., Leskovar, D., King, S. (2007). Development of a codominant CAPS marker for allelic selection between canary yellow and red watermelon based on SNP in lycopene $\beta$-cyclase (LCYB) gene. Molecular Breedin (20), 63-72

Brennan, R., Jorgensen, L., Gordon, S., Loades, K., Hackett, C., Russell, J. (2008). The development of a PCR-based marker linked to resistance to the blackcurrant gall mite (Cecidophyopsis ribis Acari: Eriophyidae). Theor. Appl. Genet. (118), 205-211. 
Brennan, R. M., Lanham, P. G., McNicol, R. J. (1993). Ribes reeding and research in the UK. Acta Horticulturae (352), 267-275. https://doi.org/10.17660/ActaHortic.1993.352.38.

Doyle, J. J., Doyle, J. L. (1990). Isolation of plant DNA from fresh tissue. Focus (12),13-15.

Gupta, P. K., Varshney, R. K., Sharma, P. C., Ramesh, B. (1999). Molecular markers and their applications in wheat breeding. Plant Breed (118),369-390.

Knight, R. L., Keep, E., Briggs, J. B., Parker, J. (1974). Transference of resistance to black currant gall mite Cecidophyopsis ribis, from gooseberry to black currant. Ann. Appl. Biol. (76),123-130.

Łabanowska, B. H., Piotrowski, W., Gruchała, M. (2015). Blackcurrant gall mite - Cecidophyopsis ribis (Westw.), harmfulness and possibility to control with fenpyroximate
(Ortus 05 SC). Prog. Plant Prot. 55 (3), 305-311.

Mazeikiene, I., Bendokas, V., Stanys, V., Siksnianas, T. (2012): Molecular markers linked to resistance to the gall mite in blackcurrant. Plant Breeding. (131),762-766.

Pluta, S., Żurawicz, E. (2002). Effect of reversion virus on the yield and fruit size in blackcurrant Ribes nigrum L. Proceedings 8th International Symposium Rubus and Ribes. Scotland, Dundee. July 2001. Acta Horticulturae 585 (1): 393-398.

Sanger, F., Coulson, A. R. (1975). A rapid method for determining sequences in DNA by primed synthesis with DNA polymerase. J Mol Biol. 94(3): 441-448.

Thiel, T, Kota, R, Grosse, I, Stein, N, Graner, A. (2004). SNP2CAPS: a SNP and INDEL analysis tool for CAPS marker development. Nucleic Acids Res; (32),e5. 